\title{
MicroRNA and mRNA expression profiling in rat acute respiratory distress syndrome
}

\author{
Chaoqun Huang ${ }^{1,3}$, Xiao Xiao ${ }^{1}$, Narendranath Reddy Chintagari ${ }^{1}$, Melanie Breshears ${ }^{2,3}$, Yang Wang ${ }^{1}$ and Lin Liu ${ }^{1,3,4^{*}}$
}

\begin{abstract}
Background: Acute respiratory distress syndrome (ARDS) is characterized by pulmonary epithelial injury and extensive inflammation of the pulmonary parenchyma. Systematic analyses of microRNA (miRNA) and mRNA expression profiling in ARDS provide insights into understanding of molecular mechanisms of the pathogenesis of ARDS. The objective of this study was to identify miRNA and mRNA interactions in a rat model of ARDS by combining miRNA and mRNA microarray analyses.
\end{abstract}

Methods: Rat model of ARDS was induced by saline lavage and mechanical ventilation. The expression profiles of both mRNAs and miRNAs in rat ARDS model were performed by microarray analyses. Microarray data were further verified by quantitative RT-PCR. Functional annotation on dys-regulated mRNAs and miRNAs was carried out by bioinformatics analysis.

Results: The expression of 27 miRNAs and 37 mRNAs were found to be significantly changed. The selected miRNAs and genes were further verified by quantitative real-time PCR. The down-regulated miRNAs included miR-24, miR-26a, miR-126, and Let-7a, b, c, f. The up-regulated miRNAs were composed of miR-344, miR-346, miR-99a, miR-127, miR-128b, miR-135b, and miR-30a/b. Gene ontology and functional annotation analyses indicated that up-regulated mRNAs, such as Apc, Timp1, and Sod2, were involved in the regulation of apoptosis. Bioinformatics analysis showed the inverse correlation of altered miRNAs with the expression of their predicted target mRNAs. While Sod2 was inversely correlated with Let-7a, b, c, f., Ebf1 and Apc were inversely correlated with miR-24 and miR-26a, respectively. miR-26a, miR-346, miR-135b, miR-30a/b, miR-344, and miR-18a targeted multiple altered mRNAs. Gabrb1, Sod2, Eif2ak1, Fbln5, and Tspan8 were targeted by multiple altered miRNAs.

Conclusion: The expressions of miRNAs and mRNAs were altered in a rat model of ARDS. The identified miRNA-mRNA pairs may play critical roles in the pathogenesis of ARDS.

Keywords: MicroRNA, mRNA, Microarray, ARDS

\section{Background}

Acute Respiratory Distress Syndrome (ARDS) is a severe lung disease that leads to a low oxygen level in the blood [1]. ARDS usually occurs in sepsis [2] or with other major injuries that may lead to multiple organ failure [3]. Lung inflammation, hypoxemia and non-cardiogenic pulmonary edema formation are characteristic features of ARDS [4]. Approximately 200,000 ALI/ARDS cases

\footnotetext{
*Correspondence: lin.liu@okstate.edu

'Department of Physiological Sciences, Lundberg-Kienlen Lung Biology and Toxicology Laboratory, Stillwater, OK, USA

${ }^{3}$ Oklahoma Center for Respiratory and Infectious Diseases, Oklahoma State University, Stillwater, OK, USA

Full list of author information is available at the end of the article
}

per year are found in the U.S. and a mortality is as high as $40 \%$ [5].

The main sites of cell injury in ARDS are vascular endothelium and alveolar epithelium. Neutrophils contribute to lung inflammation and play important roles in the pathogenesis and progression of ARDS. Lung injures cause the activation and migration of neutrophils into the pulmonary interstitium and alveolar space. The activated neutrophils damage endothelial and epithelial cells [6]. Endothelial injury leads to the increases in capillary permeability and effusion of protein-rich fluid into alveolar airspace [7]. Damage to alveolar epithelial cells causes increased entry of fluid into the alveolar lumens, 
decreased clearance of fluid from the alveolar airspace, and decreased production of surfactant [8].

MicroRNAs (miRNAs) are a class of non-coding small RNAs with approximately 22 nucleotides in length. They are important regulators of post-transcriptional gene expression. The mature miRNAs control gene expression by binding the 3'-untranslated region (3'-UTR) of its target gene, resulting in either reduced protein translation or degradation of mRNA. Many miRNAs are expressed in the lung $[9,10]$. miR-17, miR-92a and miR-127 have been shown to regulate lung development [11,12]. VEGF is a well-defined ARDS-associated candidate gene, and is a target of miR-126 [13,14]. The miRNA profiling was used to identify the miRNAs involved in the pathogenesis of various lung diseases such as ventilator-induced lung injury [15], bronchopulmonary dysplasia (BPD) [16,17], chronic obstructive pulmonary disease (COPD) [18,19], and idiopathic pulmonary fibrosis (IPF) [20,21]. However, it remains to be investigated whether miRNAs are involved in the pathogenesis of ARDS.

Genetic and environmental factors influence the susceptibility and the severity of ARDS [7]. For example, individuals with similar environmental factor exposure and prior diseases differ in their risk of developing ARDS or in their survival following ARDS, indicating a role of genetic component in the disease outcome [22,23]. Thus, it is important to investigate the contribution of genetic factors to ARDS including gene-gene and miRNA-gene interactions [24]. Because of complex and heterogenous mechanisms of human ARDS, we used a rat model of ARDS induced by saline lavage and mechanical ventilation to perform miRNA and mRNA microarray analyses simultaneously, aiming to identify miRNA-mRNA interactions and to understand the impact of these interactions on the pathogenesis of ARDS.

\section{Results \\ ARDS model}

Repeated lavage to deplete lung surfactant, followed by mechanical ventilation has been used as an experimental model of ARDS in rats [25]. Histopathological examination of lung specimens confirmed the presence of mild to moderate pulmonary lesions characterized by extensive interstitial edema, and neutrophilic infiltration in the alveolar septa and lumens in this model of ARDS (Figure 1 and Table 1). Based on the scoring system (see the Methods), all of the parameters for controls are 0 and thus were not included in Table 1 . There was minimal evidence of septal necrosis and moderate hyaline membrane formation within alveolar lumens.

\section{miRNA and mRNA expression profiles of rat ARDS}

To identify the altered miRNAs in the rat lung of ARDS, we performed miRNA profiling using an in-house printed microarray containing 227 rat miRNAs. The miRNA microarray data were deposited to the GEO database (http://www.ncbi.nlm.nih.gov/geo/, GSE57223). The results in Table 2 showed that the expression of 27 miRNAs was significantly changed based on SAM test $(\mathrm{q}<0.05)$. Among them, 20 miRNAs were up-regulated and 7 miRNAs were

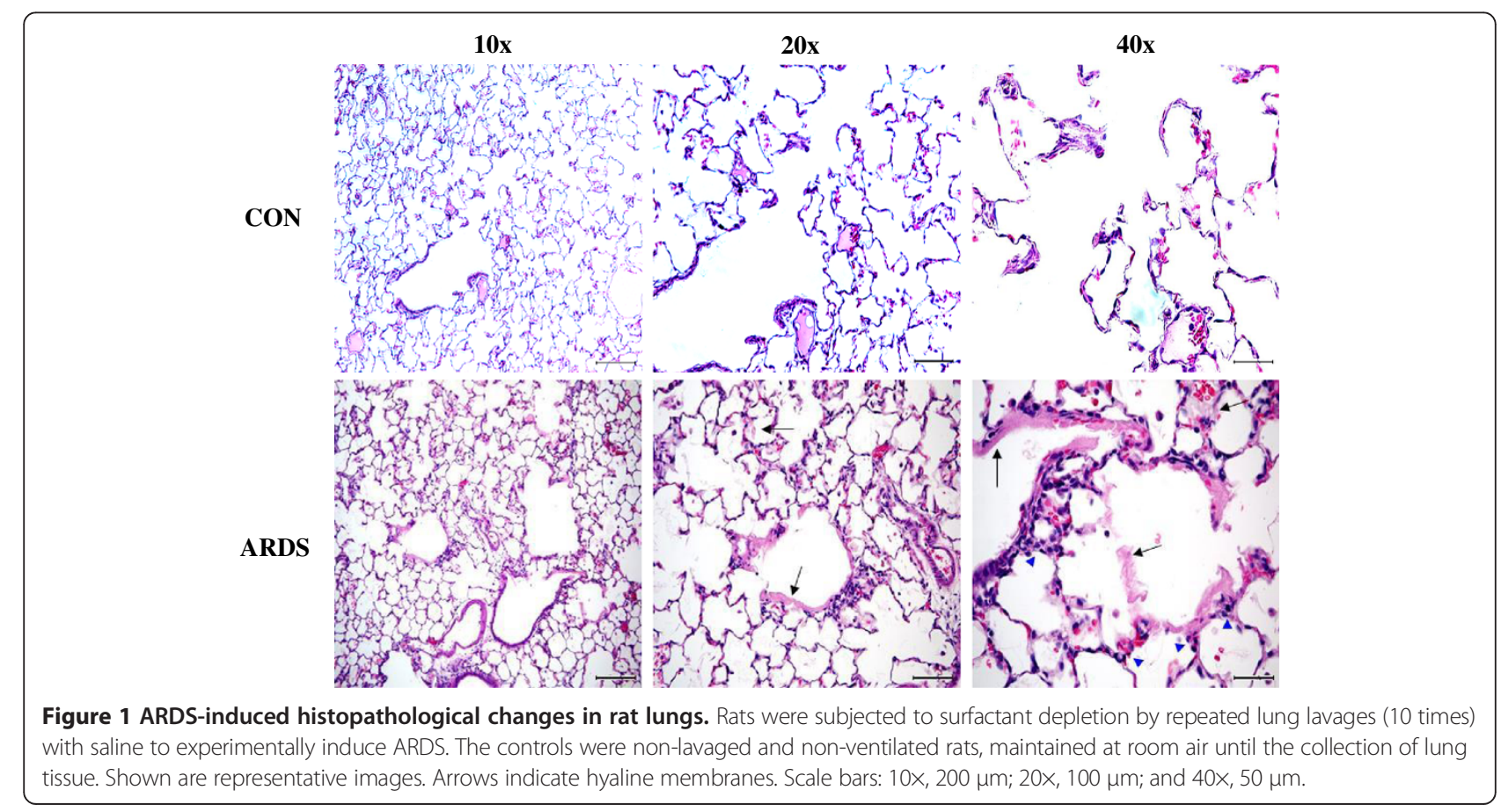


Table 1 Histopathological scores of rat ARDS ( $n=19$ rats)

\begin{tabular}{lccc}
\hline \multirow{2}{*}{ Histopathological lesion } & \multicolumn{2}{c}{ ARDS } \\
\cline { 2 - 4 } & Neutrophils & $2.00(1 ; 3)$ & $2.11 \pm 0.19$ \\
\hline Interstitial & Edema & $2.50(1 ; 3)$ & $2.42 \pm 0.19$ \\
\multirow{2}{*}{ Intraalveolar } & Neutrophils & $1.56(1 ; 3)$ & $1.52 \pm 0.18$ \\
& Edema & $1.39(1 ; 3)$ & $1.60 \pm 0.18$ \\
Alveolar septal necrosis & $1.00(1 ; 3)$ & $1.42 \pm 0.23$ \\
Hyaline membranes & $1.89(1 ; 3)$ & $1.51 \pm 0.20$ \\
\hline
\end{tabular}

Table 2 Altered miRNAs in rat ARDS

\begin{tabular}{|c|c|c|}
\hline miRNA & Fold change & q-value \\
\hline rno-miR-346 & 2.44 & $<0.05$ \\
\hline rno-miR-341 & 2.31 & $<0.05$ \\
\hline rno-miR-344 & 2.09 & $<0.05$ \\
\hline rno-miR-135b & 2.04 & $<0.05$ \\
\hline rno-miR-99a & 1.88 & $<0.05$ \\
\hline rno-miR-349 & 1.83 & $<0.05$ \\
\hline mmu-miR-380-5p & 1.82 & $<0.05$ \\
\hline rno-miR-19a & 1.76 & $<0.05$ \\
\hline rno-miR-128b & 1.75 & $<0.05$ \\
\hline rno-miR-30b & 1.74 & $<0.05$ \\
\hline rno-Let-7d* & 1.69 & $<0.05$ \\
\hline rno-miR-30a-3p & 1.66 & $<0.05$ \\
\hline rno-miR-18 & 1.65 & $<0.05$ \\
\hline rno-miR-210 & 1.64 & $<0.05$ \\
\hline rno-miR-127 & 1.61 & $<0.05$ \\
\hline rno-miR-333 & 1.59 & $<0.05$ \\
\hline rno-miR-207 & 1.59 & $<0.05$ \\
\hline rno-miR-129 & 1.55 & $<0.05$ \\
\hline rno-miR-337 & 1.51 & $<0.05$ \\
\hline rno-miR-215 & 1.51 & $<0.05$ \\
\hline rno-Let-7f & 0.59 & $<0.05$ \\
\hline rno-miR-24 & 0.58 & $<0.05$ \\
\hline rno-Let-7a & 0.52 & $<0.05$ \\
\hline rno-Let-7b & 0.5 & $<0.05$ \\
\hline rno-Let-7c & 0.48 & $<0.05$ \\
\hline rno-miR-126 & 0.47 & $<0.05$ \\
\hline rno-miR-26a & 0.47 & $<0.05$ \\
\hline
\end{tabular}

A list of increased and decreased miRNAs in rat ARDS ( $n=4$ animals) compared to normal lung samples with a q value of $<0.05$ (SAM) and a fold change of $\geq 1.5$. down-regulated. The down-regulated miRNAs included miR-24, miR-26a, miR-126, and Let-7 family members. The up-regulated miRNAs included miR-99a, miR-127, miR-128b, miR-135b, miR-30a, and miR-30b. Several selected miRNAs were validated using real-time PCR. miR-99a and miR-30b were confirmed to be the upregulated miRNAs in ARDS, while miR-126 and miR-26a were confirmed to be down-regulated miRNAs in ARDS (Figure 2).

DNA microarray was performed to identify the altered mRNAs in ARDS using an in-house printed DNA microarray containing 10,000 rat genes. The microarray data were deposited to the GEO database: http://www.ncbi. nlm.nih.gov/geo/, GSE57011. The expression of 37 genes was significantly changed based on a $\mathrm{q}$ value of $<0.05$ (SAM test) and a fold change of $\geq 2$ (Table 3). Among them, eleven genes were up-regulated and twenty six genes were down-regulated. Sod2 (Superoxide dismutase 2) and Timp1 (Metalloproteinase inhibitor 1) modulate lung injury [26,27]. Ramp2 [Receptor (calcitonin) activity modifying protein 2], Acaa2 (Acetyl-Coenzyme A acyltransferase 2), Mdh1 (Malate dehydrogenase 1, NAD), and Tspan8 (Tetraspanin 8) are enriched mRNAs in the lungs and are involved in lung disease [28,29]. These mRNAs were selected for validation by qRT-PCR. The results in Figure 3 showed that Sod2 and Timp1 were confirmed to be up-regulated in ARDS. Ramp2, Acaa2, Mdh1, and Tspan8 were confirmed to be down-regulated in ARDS.

\section{Functional annotation of the identified genes}

Functional annotation of the identified genes was carried out using David gene-GO term enrichment analysis and functional annotation clustering. The DAVID functional annotation clustering uses an algorithm to explore relationships among the annotation terms via the degrees of co-associated genes. The similar, redundant, and heterogeneous annotation contents from the same or different resources were clustered into annotation groups due to their similar biological meaning. We used DAVID default population (Rattus norvegicus) background in enrichment calculation. The functional annotation clustering was done with default parameters. Classification stringency was set as medium. The raw $\mathrm{p}$ values were used in functional annotation. The results in Table 4 showed that the up-regulated genes were involved in two functional clusters with an enrichment score of over 1.3. The results in Table 5 showed the down-regulated genes were involved in two functional clusters with an enrichment score of over 1.3. A more detailed list of genes was provided in Additional file 1.

More than 33\% of the up-regulated genes were involved in biological processes such as cellular homeostasis and regulation of apoptosis. The genes involved in apoptosis were Apc (Adenomatosis polyposis coli), Timp1, and 

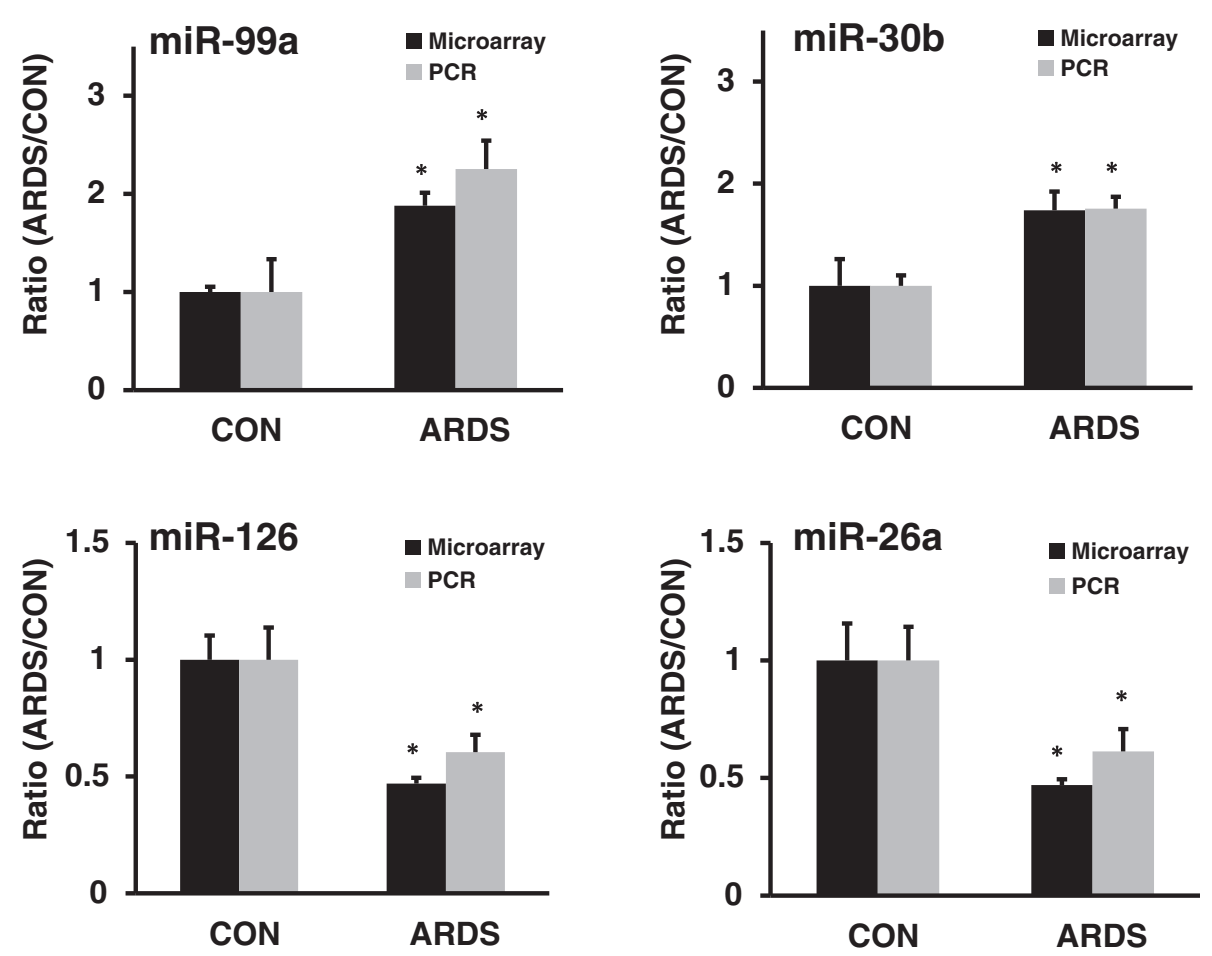

Figure 2 Validation of miRNA microarray data by real-time PCR. Small RNA was extracted from control (CON) and ARDS rat lungs. The expression of miRNAs relative to U6 RNA was determined by real-time PCR. The results were expressed as a ratio of ARDS to CON. Data are presented as means \pm S.D. from 4 animals, each assay performed in duplicate. ${ }^{*} p<0.05$, v.s. CON. Microarray: SAM test; Real-time PCR: $t$-test.

Sod2. Interestingly, a large amount of down-regulated and up-regulated genes encoded the proteins that were modified by a disulfide bond and glycosylation. Moreover, the down-regulated genes were enriched in the functional groups of acetylation and ion binding.

STRING is a web-based tool to explore GO annotation, protein-protein interactions and KEGG pathway. STRING GO enrichment is typically $\mathrm{GO}$ analysis including 3 annotations-biological process, cell compartment, and molecular function. Table 6 listed GO enrichments of the down-regulated genes in ARDS as identified by STRING GO enrichment analysis. No GO enrichment was identified for the up-regulated genes in ARDS. Using STRING, we also performed KEGG pathway enrichment analysis of the altered mRNAs in ARDS (Table 7). Eight genes including Lct (lactase-phlorizin hydrolase), Mdh1 (alate dehydrogenase 1, NAD), Akr1b1(aldo-keto reductase family 1, member B1), Alad (delta-aminolevulinic acid dehydratase), Ces3 (carboxylesterase 3), Aco2 (aconitate hydratase, mitochondrial precursor), Prdx6 (peroxiredoxin-6), and Acaa2 (acetyl-coenzyme A acyltransferase 2) were involved in the metabolic pathways. STRING analysis of proteinprotein interactions revealed 11 interactions of the protein products of altered mRNAs (Figure 4).

\section{Correlation of expression profiles between miRNAs and mRNAs}

Systematic analysis on the interactions of miRNA and mRNA using microarray data could give us information on the role of miRNAs in ARDS. Having performed miRNA and mRNA microarray profiling on the same samples, we were able to analyze the correlation between the identified altered miRNAs and mRNAs. We first predicted the genes targeted by the altered miRNA in ARDS using Targetscan (http://www.targetscan.org) and miRanda (http://www.microrna.org). Then, we compared the predicted miRNA targets with the differentially expressed mRNAs. Table 8 listed the miRNA-mRNA pairs with the inverse correlation of up-regulated miRNAs and down-regulated mRNAs as well as the down-regulated miRNAs and up-regulated mRNAs. Figure 5 showed the graphic presentation of the pairs. miRanda predicted more targets than Targetscan. The predicted miRNA binding sites in the target mRNAs by both programs were in the same location. However, miRanda predicted two rno-miR128b binding sites and TargetScan only predicted one in the 3'-UTR of Gabrb1. Among the 11 up-regulated mRNAs, Ebf1 (Early B-cell factor 1 ) was inversely correlated to miR-24. Apc and Sod2 were inversely correlated 
Table 3 Changed mRNAs in rat ARDS

\begin{tabular}{|c|c|c|c|}
\hline Gene & Full name & $\begin{array}{l}\text { Fold } \\
\text { change }\end{array}$ & q-value \\
\hline Mt3 & Metallothionein 3 & 43.49 & $<0.05$ \\
\hline S100a9 & $\begin{array}{l}\text { S100 calcium binding protein } \\
\text { A9 (calgranulin B) }\end{array}$ & 6.81 & $<0.05$ \\
\hline Prdx6 & Peroxiredoxin-6 & 5.89 & $<0.05$ \\
\hline TIMP1 & Metalloproteinase inhibitor 1 & 5.79 & $<0.05$ \\
\hline $\mathrm{Ccl} 2$ & Chemokine (C-C motif) ligand 2 & 3.90 & $<0.05$ \\
\hline Sod2 & $\begin{array}{l}\text { Superoxide dismutase } 2, \\
\text { mitochondrial }\end{array}$ & 2.98 & $<0.05$ \\
\hline Len2 & Lipocalin 2 & 2.59 & $<0.05$ \\
\hline Ifrd1 & $\begin{array}{l}\text { Interferon-related developmental } \\
\text { regulator } 1\end{array}$ & 2.16 & $<0.05$ \\
\hline Apc & Adenomatosis polyposis coli & 2.02 & $<0.05$ \\
\hline Ebf1 & Early B-cell factor 1 & 2.00 & $<0.05$ \\
\hline Mt2a & $\begin{array}{l}\text { metallothionein-2 and } \\
\text { metallothionein-1 genes }\end{array}$ & 2.00 & $<0.05$ \\
\hline Cyb5 & Cytochrome b5 & 0.52 & $<0.05$ \\
\hline L20990 & T cell receptor & 0.51 & $<0.05$ \\
\hline Serpinh1 & $\begin{array}{l}\text { Serine (or cysteine) proteinase inhibitor, } \\
\text { clade } \mathrm{H} \text {, member } 1\end{array}$ & 0.5 & $<0.05$ \\
\hline S100a4 & S100 calcium-binding protein A4 & 0.49 & $<0.05$ \\
\hline Eif2ak1 & $\begin{array}{l}\text { Eukaryotic translation initiation factor } \\
\text { 2-alpha kinase } 1\end{array}$ & 0.49 & $<0.05$ \\
\hline Fbln5 & Fibulin 5 & 0.48 & $<0.05$ \\
\hline Aco2 & Aconitase 2, mitochondrial & 0.48 & $<0.05$ \\
\hline Akr1b4 & $\begin{array}{l}\text { Aldo-keto reductase family } 1 \\
\text { member B4 (aldose reductase) }\end{array}$ & 0.47 & $<0.05$ \\
\hline Lct & $\begin{array}{l}\text { Lactase-phlorizinhydrolaseLactase } \\
\text { Phlorizin hydrolase }\end{array}$ & 0.47 & $<0.05$ \\
\hline Slc25a11 & $\begin{array}{l}\text { Solute carrier family } 25 \text { (mitochondrial } \\
\text { carrier; oxoglutarate carrier), } \\
\text { Member } 11\end{array}$ & 0.47 & $<0.05$ \\
\hline Ramp2 & $\begin{array}{l}\text { Receptor (calcitonin) activity } \\
\text { modifying protein } 2\end{array}$ & 0.47 & $<0.05$ \\
\hline G8 & G8 gene & 0.46 & $<0.05$ \\
\hline Acaa2 & $\begin{array}{l}\text { Acetyl-Coenzyme A acyltransferase } 2 \\
\text { (mitochondrial 3-oxoacyl-Coenzyme } \\
\text { A thiolase) }\end{array}$ & 0.43 & $<0.05$ \\
\hline Gabrb1 & $\begin{array}{l}\text { Gamma-aminobutyric acid (GABA-A) } \\
\text { receptor, subunit beta } 1\end{array}$ & 0.43 & $<0.05$ \\
\hline M13801 & $\begin{array}{l}\text { Ig germline alpha H-chain C-region } \\
\text { gene }\end{array}$ & 0.42 & $<0.05$ \\
\hline Septin 5 & Septin 5 & 0.4 & $<0.05$ \\
\hline Mdh1 & $\begin{array}{l}\text { Malate dehydrogenase } 1, N A D \\
\text { (soluble) }\end{array}$ & 0.39 & $<0.05$ \\
\hline Psma4 & $\begin{array}{l}\text { Proteasome (prosome, macropain) } \\
\text { subunit, alpha type } 4\end{array}$ & 0.39 & $<0.05$ \\
\hline Alad & Aminolevulinate, delta-, dehydratase & 0.38 & $<0.05$ \\
\hline lgfbp6 & $\begin{array}{l}\text { Insulin-like growth factor binding } \\
\text { protein } 6\end{array}$ & 0.37 & $<0.05$ \\
\hline Ces3 & Carboxylesterase 3 & 0.35 & $<0.05$ \\
\hline
\end{tabular}

Table 3 Changed mRNAs in rat ARDS (Continued)

\begin{tabular}{|c|c|c|c|}
\hline U06230 & protein $\mathrm{S}$ mRNA & 0.31 & $<0.05$ \\
\hline Fgfr4 & $\begin{array}{l}\text { Fibroblast growth factor receptor } \\
\text { subtype } 4 \text { (FGFR4) mRNA }\end{array}$ & 0.27 & $<0.05$ \\
\hline $\operatorname{Lim} 2$ & Lens intrinsic membrane protein 2 & 0.24 & $<0.05$ \\
\hline Tspan8 & Tetraspanin 8 & 0.24 & $<0.05$ \\
\hline Gnrh1 & $\begin{array}{l}\text { Progonadoliberin-1Gonadoliberin-1 } \\
\text { Prolactin release-inhibiting factor } 1\end{array}$ & 0.08 & $<0.05$ \\
\hline
\end{tabular}

with miR-26a. Sod2 was inversely correlated with Let-7a, b, c, $\mathrm{f}$. We also identified the inverse correlation of many upregulated miRNAs and down-regulated mRNAs. miR-346, miR-135b, miR-30a/b, miR-344, and miR-18a had more than one mRNA target. Gabrb1 (Gamma-aminobutyric acid (GABA-A) receptor, subunit beta 1), Sod2, Eif2ak1 (Eukaryotic translation initiation factor 2-alpha kinase 1), Fbln5 (Fibulin 5), and Tspan8 were targeted by multiple miRNAs.

GO analysis was applied to the up- and down-regulated genes that were inversely related to the altered miRNAs. We found that cofactor and coenzyme metabolic processes were the top GO categories of these mRNAs (Figure 6).

\section{Mapping miRNAs to signaling pathways}

DIANA-mirPath is a web-based computational tool to identify signaling pathways regulated by miRNAs [32]. The software compares each set of miRNA targets with all known KEGG pathways to identify the number of miRNA target genes in the pathways. ErbB, MAPK, and WNT signaling pathways had high scores and were likely to be controlled by the altered miRNAs in ARDS (Table 9).

\section{Discussion}

ARDS is a respiratory disease linked to numerous factors including cytokines, oxidants, and growth factors [33-37]. Functional genomics approaches provide novel insights into understanding gene-environmental interactions controlling this complex process. In our present study, we aimed to identify genes that play critical roles in regulating the pathogenesis of ARDS, and to determine how miRNAs contribute to the regulation of these genes. Key to our approach was microarray analyses to obtain mRNA and miRNA expression profiles in ARDS.

The expression profiles of both miRNAs and mRNAs allow us to determine whether there is a correlation between the expression levels of miRNAs and target mRNAs. We found that up-regulated miRNAs (miR-346, miR135b, miR-30ab, miR-344, miR-18a, miR-99a, miR-210, miR-207, miR-18a, and miR-129) in ARDS were inversely 


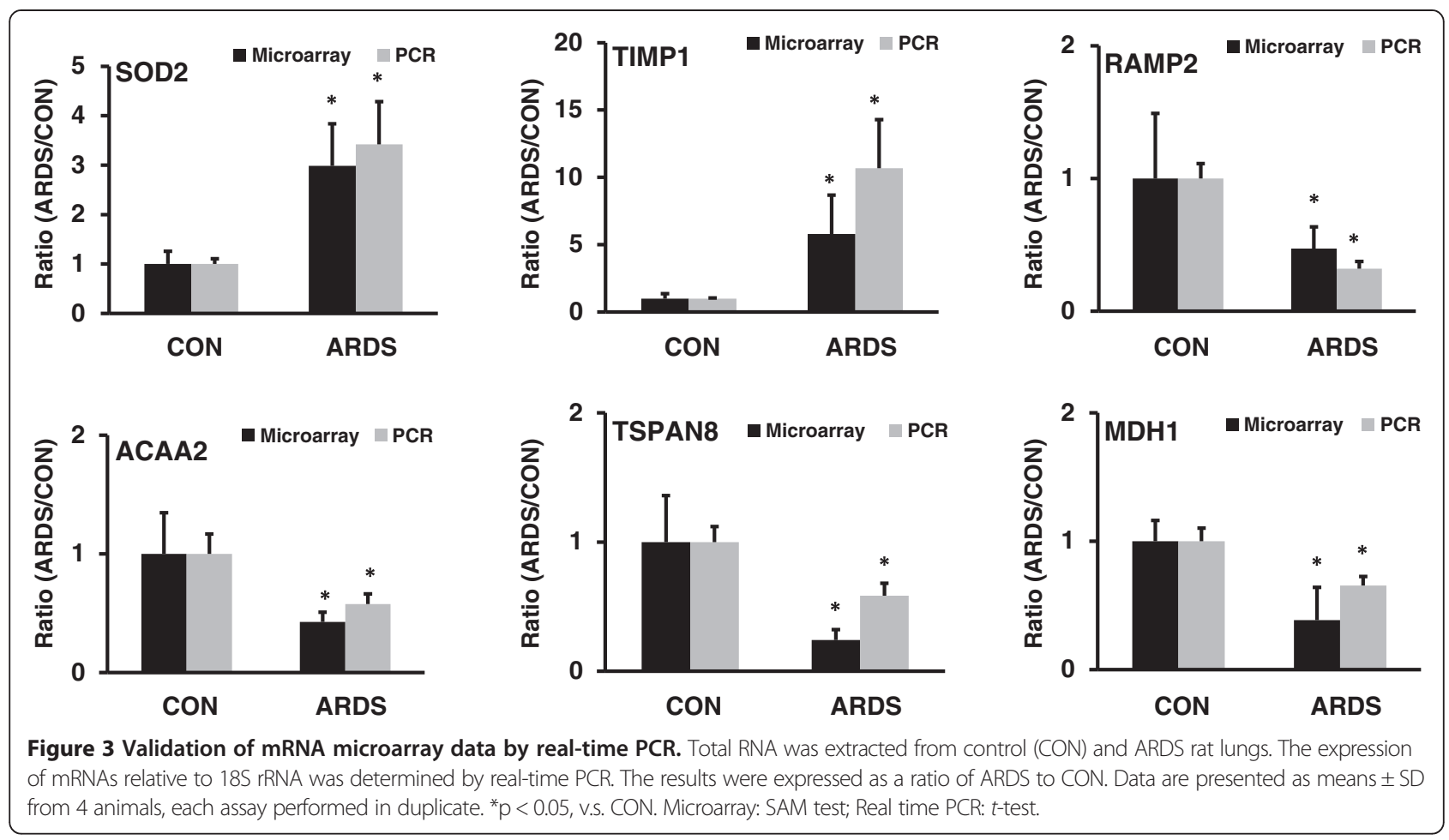

Table 4 Functional annotation clustering of up-regulated genes

\begin{tabular}{|c|c|c|c|c|}
\hline Annotation cluster 1 & Enrichment score: 2.44 & & & \\
\hline Category & Term & Count & $\%$ & $P$ value \\
\hline GOTERM_BP_FAT & GO:0019725 cellular homeostasis & 5 & 56 & $<0.001$ \\
\hline GOTERM_BP_FAT & GO:0055066 di-, tri-valent inorganic cation homeostasis & 3 & 33 & 0.003 \\
\hline GOTERM_BP_FAT & GO:0055080 cation homeostasis & 3 & 33 & 0.005 \\
\hline GOTERM_BP_FAT & GO:0006873 cellular ion homeostasis & 3 & 33 & 0.010 \\
\hline GOTERM_BP_FAT & GO:0055082 cellular chemical homeostasis & 3 & 33 & 0.010 \\
\hline GOTERM_BP_FAT & GO:0050801 ion homeostasis & 3 & 33 & 0.012 \\
\hline GOTERM_BP_FAT & GO:0048878 chemical homeostasis & 3 & 33 & 0.018 \\
\hline Annotation cluster 2 & Enrichment score: 1.82 & & & \\
\hline GOTERM_BP_FAT & GO:0043066 negative regulation of apoptosis & 3 & 33 & 0.008 \\
\hline GOTERM_BP_FAT & GO:0043069 negative regulation of programmed cell death & 3 & 33 & 0.008 \\
\hline GOTERM_BP_FAT & GO:0060548 negative regulation of cell death & 3 & 33 & 0.008 \\
\hline GOTERM_BP_FAT & GO:0030097 hemopoiesis & 3 & 33 & 0.009 \\
\hline GOTERM_BP_FAT & GO:0048534 hemopoietic or lymphoid organ development & 3 & 33 & 0.011 \\
\hline GOTERM_BP_FAT & GO:0002520 immune system development & 3 & 33 & 0.012 \\
\hline GOTERM_BP_FAT & GO:0042981 regulation of apoptosis & 3 & 33 & 0.039 \\
\hline GOTERM_BP_FAT & GO:0043067 regulation of programmed cell death & 3 & 33 & 0.040 \\
\hline GOTERM_BP_FAT & GO:0010941 regulation of cell death & 3 & 33 & 0.041 \\
\hline
\end{tabular}

The functional annotation of mRNA expression profile was conducted by DAVID software (http://david.abcc.ncifcrf.gov) [30,31]. Annotation Cluster: a group of terms having similar biological functions. Enrichment Score: The geometric mean (in -log scale) of member's p-values in a corresponding annotation cluster is the rank of their biological significance. The higher an enrichment score, the more enriched genes in that group. An enrichment score of $>1.3$ is used for a cluster to be statistically significant. P-Value: The p-values associated with each annotation terms are the Fisher Exact Score shown in the regular chart report for the same terms. Count: Genes involved in the terms. \%: Percentage of involved genes over total up-regulated genes correlated to altered miRNAs. 
Table 5 Functional annotation clustering of down-regulated genes

\begin{tabular}{lcccc}
\hline Annotation cluster $\mathbf{1}$ & Enrichment score: $\mathbf{1 . 3 8}$ & Count & \% & P value \\
\cline { 2 - 4 } Category & Term & 8 & 38 & 0.014 \\
\hline SP_PIR_KEYWORDS & Disulfide bond & 9 & 43 & 0.034 \\
SP_PIR_KEYWORDS & Glycoprotein & 8 & 38 \\
UP_SEQ_FEATURE & Signal peptide & 8 & 38 \\
SP_PIR_KEYWORDS & Signal & 8 & 38 \\
UP_SEQ_FEATURE & Glycosylationsite: N-linked (GlcNAc...) & 0.035 \\
UP_SEQ_FEATURE & Disulfide bond & 6 & 29 \\
\hline
\end{tabular}

The functional annotation of mRNA expression profile was conducted by DAVID software (http://david.abcc.ncifcrf.gov) [30,31]. Annotation Cluster: A group of terms having similar biological functions. Enrichment Score: The geometric mean (in -log scale) of member's p-values in a corresponding annotation cluster represents the rank of their biological significance. An enrichment score of $>1.3$ is used for a cluster to be statistically significant. The higher an enrichment score, the more enriched genes in that group. P-Value: The p-values associated with each annotation terms are the Fisher Exact Score shown in the regular chart report for the same terms. Count: Genes involved in the terms. \%: Percentage of involved genes over total down-regulated genes correlated to altered miRNAs.

correlated with the expression of their predicted targets such as Gabrb1, Mdh1, Eif2ak1, Fbln5, and Tspan8. miR346, miR-135b, miR-30ab, miR-344, and miR-18a were inversely correlated with more than one mRNA targets. Gabrb1, Sod2, Eif2ak1, Fbln5, Tspan8 were targeted by several miRNAs. Moreover, we found that the downregulated miRNAs, miR-26a, miR-24, and miR-Let-7abcf family, were inversely related to their predicted mRNA targets, Sod2, and Ebf1. miRNA expression patterns have previously been investigated in lung injury models. Let-7 is

Table 6 GO enrichments of the down-regulated genes in ARDS using STRING analysis

\begin{tabular}{|c|c|c|c|c|c|}
\hline Go enrichment & GO_id & Term & Number of genes & p-value & Involved genes \\
\hline \multirow[t]{16}{*}{ Biological process } & GO:0046501 & Protoporphyrinogen IX metabolic process & 2 & $1.15 \mathrm{E}-04$ & Eif2ak1, Alad \\
\hline & GO:0030198 & Extracellular matrix organization & 2 & 4.84E-03 & Ramp2, Flbn5 \\
\hline & GO:0043062 & Extracellular structure organization & 2 & 4.84E-03 & Ramp2, Flbn5 \\
\hline & GO:0044242 & Cellular lipid catabolic process & 2 & $5.73 \mathrm{E}-03$ & Acaa2, Ces3 \\
\hline & GO:0046777 & Protein autophosphorylation & 2 & 8.67E-03 & Eif2ak1, Fgfr4 \\
\hline & GO:0030162 & Regulation of proteolysis & 2 & $1.25 \mathrm{E}-02$ & Serpinh1, Fgfr4 \\
\hline & GO:0055114 & Oxidation-reduction process & 3 & $1.33 \mathrm{E}-02$ & Acaa2, Cyb5, Mdh1 \\
\hline & GO:0070613 & Regulation of protein processing & 2 & $1.70 \mathrm{E}-02$ & Serpinh1, Fgfr4 \\
\hline & GO:0045471 & Response to ethanol & 2 & $1.90 \mathrm{E}-02$ & Gnrh1, Lct \\
\hline & GO:0016042 & Lipid catabolic process & 2 & $1.90 \mathrm{E}-02$ & Acaa2, Ces3 \\
\hline & GO:0080134 & Regulation of response to stress & 3 & $2.22 \mathrm{E}-02$ & Eif2ak1, Fbln5, Tspan8 \\
\hline & GO:0051186 & Cofactor metabolic process & 2 & $2.69 \mathrm{E}-02$ & Eif2ak1, Acaa2 \\
\hline & GO:0080135 & Regulation of cellular response to stress & 2 & $3.49 \mathrm{E}-02$ & Eif2ak1, Fbln5 \\
\hline & GO:0071363 & Cellular response to growth factor stimulus & 2 & $3.94 \mathrm{E}-02$ & Ramp2, Fgfr4 \\
\hline & GO:0048583 & Regulation of response to stimulus & 5 & 4.70E-02 & Ramp2, Flbn5, Eif2ak1, Fgfr4, Tspan8 \\
\hline & GO:0070848 & Response to growth factor & 2 & 4.81E-02 & Ramp2, Fgfr4 \\
\hline \multirow[t]{7}{*}{ Molecular function } & GO:0016836 & Hydro-lyase activity & 2 & 0.000481 & Aco2, Alad \\
\hline & GO:0016835 & Carbon-oxygen lyase activity & 2 & 0.00106 & Aco2, Alad \\
\hline & GO:0016829 & Lyase activity & 2 & 0.0102 & Aco2, Alad \\
\hline & GO:0020037 & Heme binding & 2 & 0.0153 & Eif2ak1, Cyb5 \\
\hline & GO:0046906 & Tetrapyrrole binding & 2 & 0.0164 & Eif2ak1, Cyb5 \\
\hline & GO:0044822 & Poly(A) RNA binding & 4 & 0.0255 & Serpinh1, S100a4, Acaa2, Slc25a11 \\
\hline & GO:0003723 & RNA binding & 4 & 0.0313 & Serpinh1, S100a4, Acaa2, Slc25a11 \\
\hline \multirow[t]{3}{*}{ Cellular component } & GO:0005788 & Endoplasmic reticulum lumen & 2 & $2.38 \mathrm{E}-03$ & Ces3, serpineh 1 \\
\hline & GO:0044432 & Endoplasmic reticulum part & 3 & $3.15 \mathrm{E}-02$ & Ces3, serpineh 1, Cyb5 \\
\hline & GO:0005739 & Mitochondrion & 4 & $3.94 \mathrm{E}-02$ & Aco2, Mdh1, Slc25a11, Acaa2 \\
\hline
\end{tabular}

GO_id with a $p$ value of $<0.05$ was selected. 
Table 7 Signaling pathways predicted to be regulated by altered mRNAs in rat ARDS

\begin{tabular}{ccc}
\hline Term & Number of genes & p-value \\
\hline Glyoxylate and dicarboxylate metabolism & 2 & 0.000868 \\
Galactose metabolism & 2 & 0.00172 \\
Citrate cycle (TCA cycle) & 2 & 0.00327 \\
Pyruvate metabolism & 2 & 0.00475 \\
Metabolic pathways & 8 & 0.00753
\end{tabular}

Analysis of KEGG pathway enrichment in the altered mRNAs in rat ARDS was performed by STRING analysis. Pathways with a $p$ value of $<0.05$ were selected.

altered in a mouse model of ventilator-induced lung injury [15]. We also found that Let-7 family was downregulated in ARDS. miR-126, a regulator of angiogenic signaling and vascular integrity, has been reported to be involved in ARDS/ALI and VEGF is identified as a target of miR-126 [13,14]. Moreover, miR-126 also plays a role in neoangiogenesis of adult tissues in response to injury [38]. In the present study, we found that miR-126 was down-regulated in ARDS. However, we did not find the correlation of miR-126 to the identified altered mRNAs in ARDS.

The major aims of the present study were to identify altered miRNAs and mRNAs in rat ARDS through microarray analyses, and to correlate the identified altered miRNAs and mRNAs by computational prediction. One limitation of the current study was that we did not further validate the predicted miRNA-mRNA interactions. However, some of the predicted miRNA-mRNA interactions from the present study can be found in the Tarbase/ mirRecords database, which documented experimentally verified miRNA-mRNA pairs. For example, miR-26a-APC pair was experimentally validated [39]. The second limitation was that we did not answer whether these interactions were biologically important in vivo. Since miRNA can

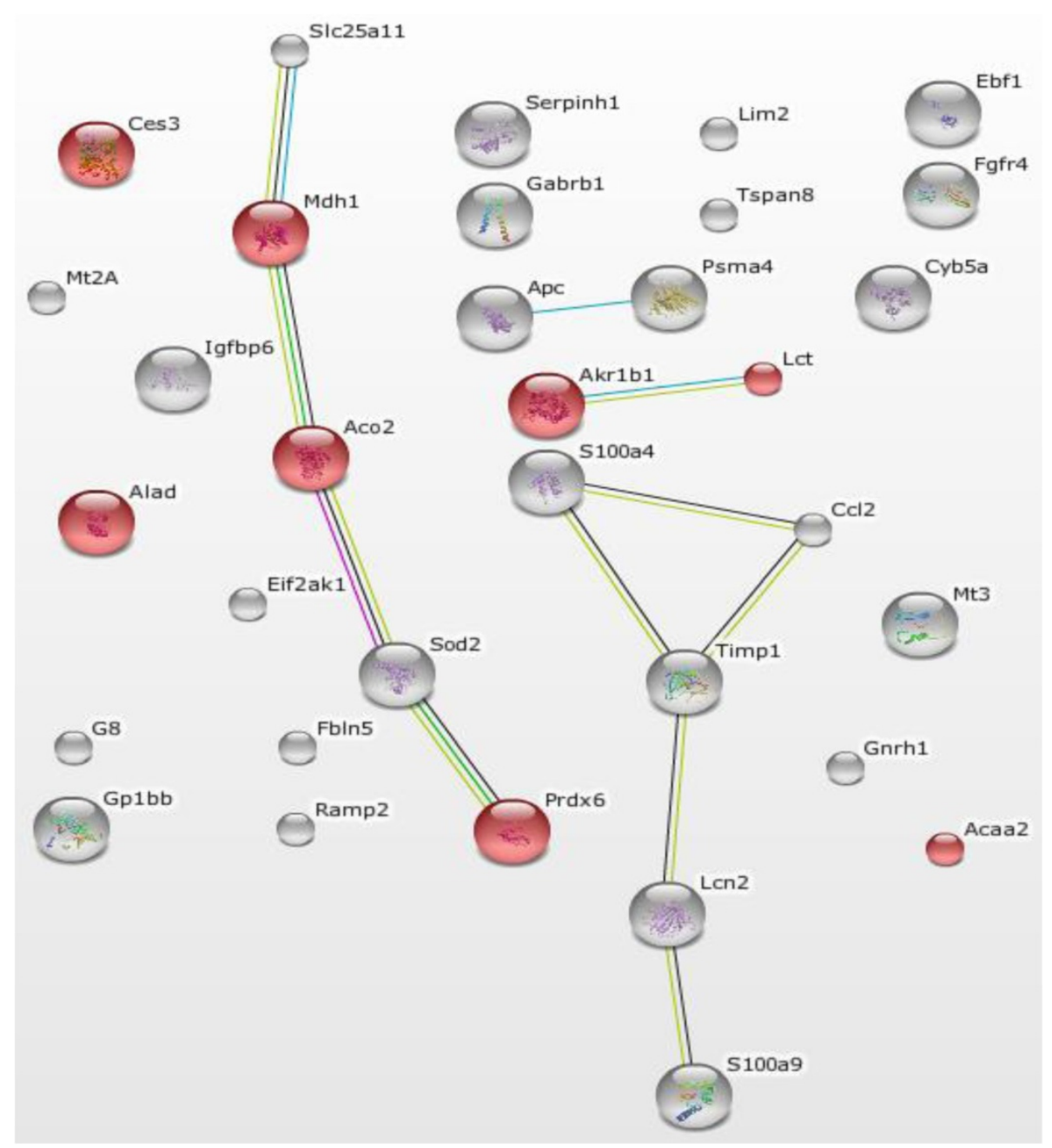

Figure 4 STRING analysis of pathway enrichment and interaction in the altered mRNA in rat ARDS. Eight mRNAs, Lct, Mdh1, Akr1b1, Alad, Ces3, Aco2, Prdx6, and Acaa2 were involved in the metabolic pathways (pink color). Eleven interactions were observed in the protein products of altered mRNAs (connected node). 
Table 8 Inverse correlation of mRNAs and miRNAs

\begin{tabular}{|c|c|c|c|c|}
\hline miRNA & & Targetscan & miRanda & mRNA \\
\hline \multirow[t]{26}{*}{ Up-regulated } & miR-346 & Tspan8 & Tspan8 & Down-regulated \\
\hline & & Mdh1 & Mdh1 & \\
\hline & & & Fbln5 & \\
\hline & miR-135b & & Acaa2 & \\
\hline & & & Ces3 & \\
\hline & & & Ramp2 & \\
\hline & & & Serpinh1 & \\
\hline & miR-99a & & Eif2ak1 & \\
\hline & miR-210 & & Fbln5 & \\
\hline & miR-19a & & Fbln5 & \\
\hline & miR-30ab & Gabrb1 & Gabrb1 & \\
\hline & & & Mdh1 & \\
\hline & miR-128b & Gabrb1 & Gabrb1 & \\
\hline & & Tspan8 & Tspan8 & \\
\hline & miR-207 & Alad & Fbln5 & \\
\hline & & Slc25a11 & & \\
\hline & miR-344 & & Aco2 & \\
\hline & & & Mdh1 & \\
\hline & & & Eif2ak1 & \\
\hline & miR-380 & & AcO2 & \\
\hline & miR-337 & & Eif2ak1 & \\
\hline & miR-18a & & Fbln5 & \\
\hline & & & Igfbp6 & \\
\hline & miR-349 & Serpinh1 & & \\
\hline & miR-129 & & AcO2 & \\
\hline & & & Mdh1 & \\
\hline \multirow[t]{3}{*}{ Down-regulated } & miR-24 & Ebf1 & & Up-regulated \\
\hline & miR-26a & Apc & Sod2 & \\
\hline & Let-7abcf & & Sod2 & \\
\hline
\end{tabular}

Tspan8: Tetraspanin 8; Mdh1: Malate dehydrogenase; Fbln5: Fibulin 5; Acaa2: Acetyl-Coenzyme A acyltransferase 2; Ces3: Carboxylesterase 3; Ramp2: Receptor activity modifying protein 2; Serpinh1: Serine (or cysteine) proteinase inhibitor, clade $\mathrm{H}$, member 1; Eif2ak1: Eukaryotic translation initiation factor 2-alpha kinase 1; Gabrb1: Gamma-aminobutyric acid (GABA-A) receptor, subunit beta 1; Alad: Aminolevulinate, delta-, dehydratase; SIc25a11: Solute carrier family 25 (mitochondrial carrier; oxoglutarate carrier), Member 11; Aco2: Aconitase 2; Igfbp6: Insulin-like growth factor binding protein 6; Ebf1: Early B-cell factor 1; Apc: Adenomatosis polyposis coli; Sod2: Superoxide dismutase 2.

inhibit the protein translation without mRNA degradation, the third limitation is that our current approach can not identify these interactions between miRNAs and proteins.

Gene ontology and functional annotation analyses facilitate interpreting the biological relevance of mRNA expression profile in ARDS. More than $50 \%$ of the up-regulated genes in ARDS were involved in cellular homeostasis. Cells are essentially factories which strictly maintain their intracellular environment so that conditions remain optimal for performing tasks that take place inside the cells. Chemical and ion homeostasis are important to the cells. Thus, it is of interest to hypothesize that the alteration of the genes involved in cellular homeostasis contributes to the pathogenesis of ARDS. We also found that more than 33\% of the up-regulated genes in ARDS were involved in the regulation of apoptosis. These genes included Apc, Timp1, and Sod2. Apoptosis of epithelial and endothelial cells has been observed in the lung of ARDS patients [40]. Apoptosis mediators are also increased in the BAL (bronchoalveolar lavage) fluid of ARDS patients [41]. A delayed apoptosis of intra-alveolar neutrophils with a concomitant increased apoptosis of alveolar epithelium increases the severity of lung injury [41]. Moreover, miRNAs are also involved in the regulation of apoptosis. Up-regulation of miR-26a promotes apoptosis in rat neonatal cardiomyocytes via the caspase-3 pathway [42] while down-regulation of miR-26a antagonizes apoptosis by targeting MTDH and EZH2 in breast cancer [43]. Let-7 is also a regulator of apoptosis in tumors [44]. Interestingly, the down-regulated miRNAs, miR-26a and Let-7abcf family in our ARDS model were inversely related to the expression of Apc and Sod2 which were involved in regulation of apoptosis.

Some of the identified down-regulated miRNAs in ARDS are involved in pulmonary fibrosis [20,45] and lung cancer [46], while the up-regulated miRNAs play critical roles in lung development [12] and in the pathogenesis of lung cancer [47-50]. Among these miRNAs, Let-7 is involved in the airway inflammation by directly regulating IL-13 expression [51]. miR-126 controls leukocyte infiltration into inflamed lungs by repressing ALCAM expression [52]. In addition, miR-126 is down-regulated in cystic fibrosis that is characterized by chronic airway inflammation. miR-126 controls TLR2/4 inflammatory signaling pathways by modulating TOM1 expression in cystic fibrosis lung [45].

The cofactor and coenzyme metabolic processes were on the top list of GO category of mRNAs targeted by altered miRNAs. The changes in cofactor metabolism have been reported in ARDS. Hypoxanthine is a key cofactor that accumulates during hypoxia, leading to the production of $\mathrm{O}_{2}{ }^{--}$and $\mathrm{H}_{2} \mathrm{O}_{2}$, and is significantly elevated in the plasma from ARDS patients [53]. C5a-dependent chemotactic activity is also increased in BAL fluid of ARDS patients [54]. Von Willebrand factor antigen (vWF:Ag) in the vascular endothelial cells acts as a ristocetin cofactor and is related to the development of ARDS [55,56]. Leptin, a potential cofactor involved in lung fibroproliferative responses is increased in the BAL fluid of ARDS patients. The elevated levels of leptinin BAL fluid are associated with a higher mortality [57]. These findings suggest that miRNAs may play roles in the pathogenesis of ARDS by targeting genes that regulate cofactor and coenzyme metabolism. 


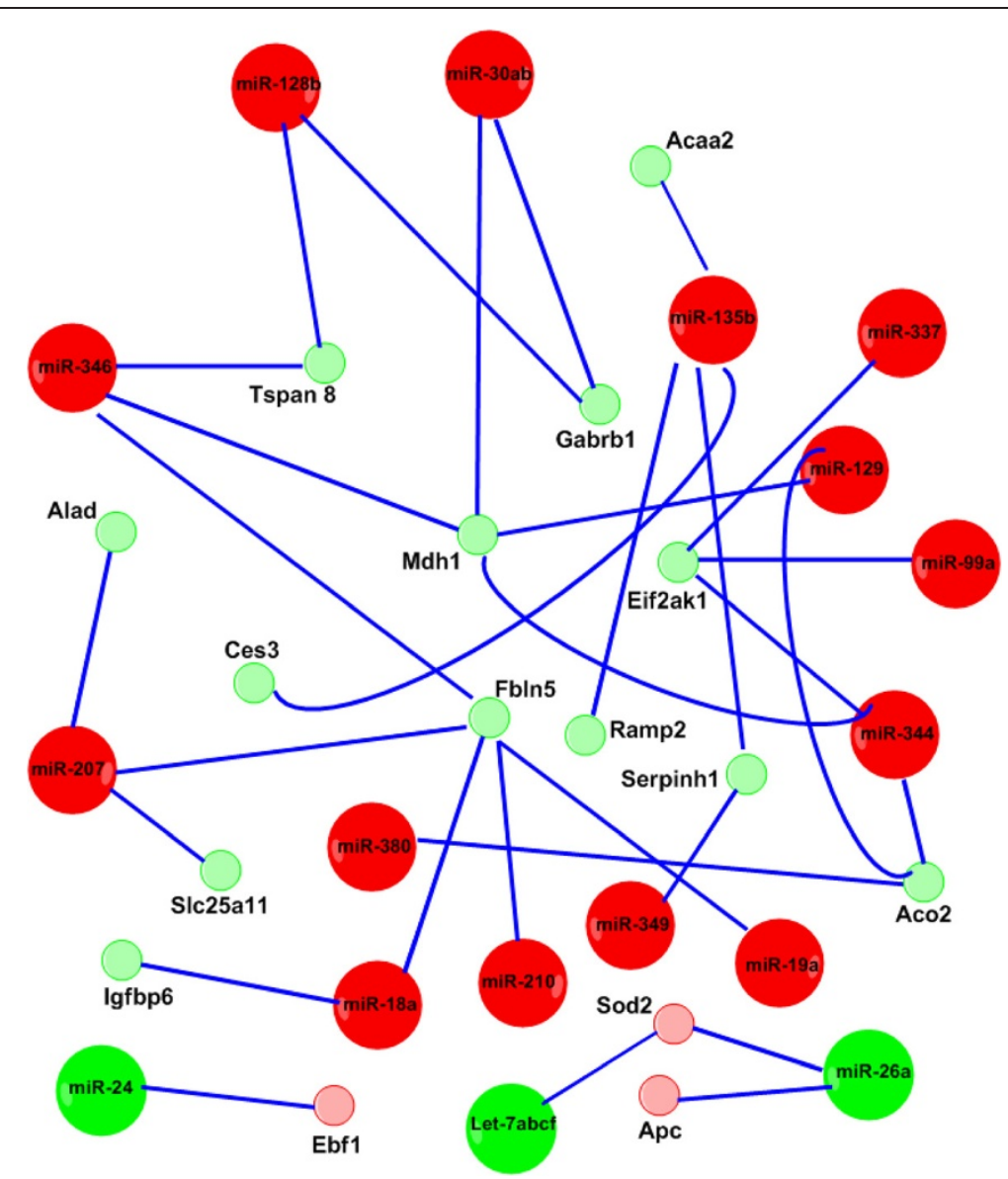

Figure 5 Interaction network of miRNAs and mRNAs in ARDS. The miRNA-mRNA interacting network was constructed using the altered mRNAs and miRNAs in ARDS identified in our microarray analyses. The mRNAs were the predicted targets of miRNAs and inversely correlated with miRNAs. Red: up-regulated miRNAs; Green: down-regulated miRNAs; Pink: up-regulated mRNAs; Light green: down-regulated mRNAs.

Extracellular signals cause the alterations in gene expression and metabolism in cells via signal transduction. Abnormal activation or inhibition of multiple signaling pathways often results in lung diseases. WNT/ $\beta$-catenin signaling pathway plays an important role in lung injury and repair [58]. We mapped the altered miRNAs to signaling pathways by software DIANA-mirPath. ErbB, MAPK, and WNT signaling pathways were found to be controlled by these altered miRNAs in ARDS. Interestingly, miR-26a was inversely correlated with the expression of Apc. The adenomatous polyposis coli tumor-suppressor protein, APC encoded by Apc gene is a negative regulator of WNT signaling.

\section{Conclusion}

In the present study, using miRNA and mRNA microarray analyses, we systematically examined the expression of mRNAs and miRNAs in ARDS, and correlated their expression. This is the first report to integrate miRNA expression data with mRNA expression data in ARDS.
The identified miRNAs and mRNAs may be critical in the pathogenesis of ARDS.

\section{Methods}

\section{Rat model of ARDS}

Adult male Sprague Dawley rats (250-300 gms) were used for this study. All the procedures were approved by Institutional Animal Care and Use Committee at the Oklahoma State University. Rat model of ARDS was induced by saline lavage and mechanical ventilation [25,59] (Figure 7). In brief, rats were anesthetized with intraperitoneal injection of ketamine $[80 \mathrm{mg} / \mathrm{kg}$ body wight $(B W)]$ and xylazine $(10 \mathrm{mg} / \mathrm{kg} \mathrm{BW})$. The animals were then placed on a heated water pad maintained at $37^{\circ} \mathrm{C}$ for the entire length of the procedure. A tracheotomy was performed. A blunt canula was inserted and secured. The animals were ventilated with $100 \%$ oxygen at a respiratory rate of 30 breaths $/ \mathrm{min}$, a Vt of $8 \mathrm{ml} / \mathrm{kg}$ BW, an inspiration: expiration ratio of $1: 2$, and a PEEP of $3 \mathrm{~cm} \mathrm{H}_{2} \mathrm{O}$. An intramuscular injection of pancuronium bromide $(1 \mathrm{ml} / \mathrm{kg}, \mathrm{BW})$ was administered for muscle 


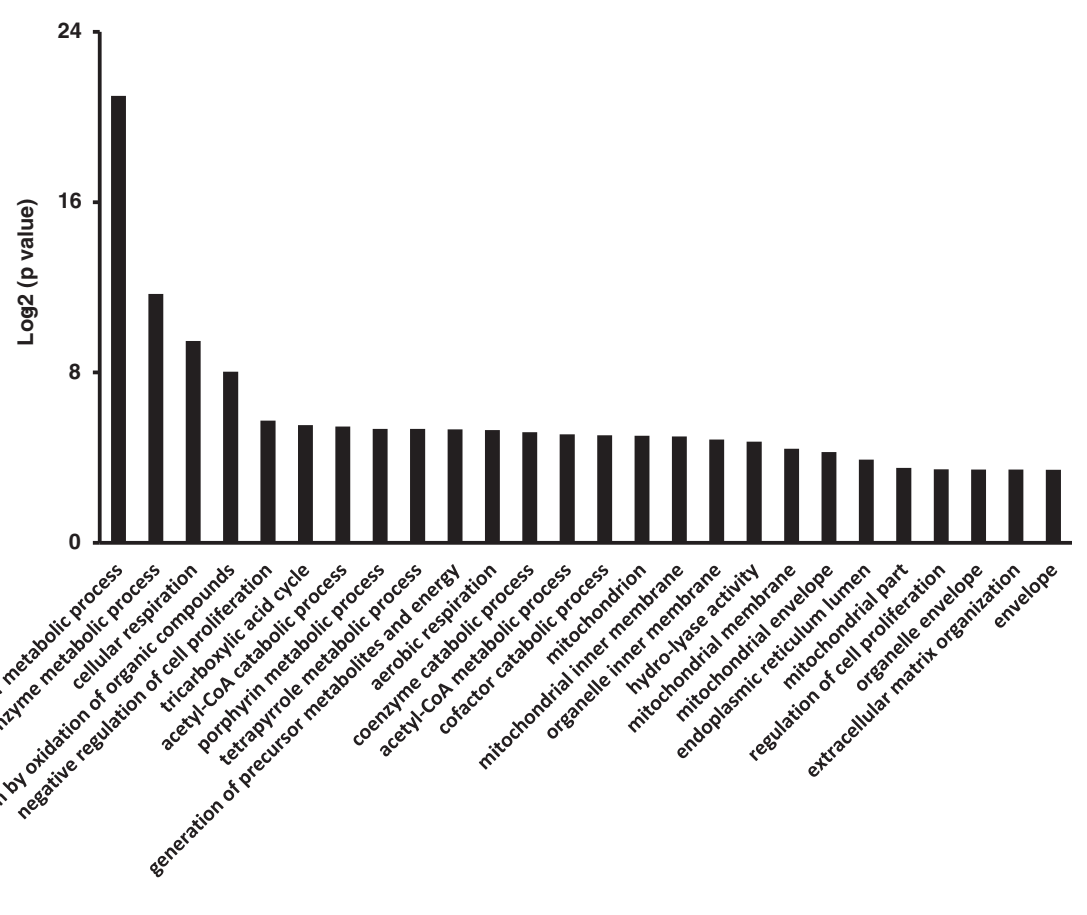

Figure 6 Identification of functional categories of mRNAs targeted by altered miRNAs in rat ARDS. GO analysis was performed on mRNAs which were identified by Targetscan or miRanda, and inversely correlated with miRNAs. Only categories with a p-value less than 0.05 were included. The negative log2 of the p-value was plotted on the Y-axis.

relaxation and preventing spontaneous breathing. After $15 \mathrm{~min}$ ventilation, Vt was increased to $16 \mathrm{ml} / \mathrm{kg}$ and PEEP to $8 \mathrm{~cm} \mathrm{H}_{2} \mathrm{O}$. The ventilation was continued for an additional $15 \mathrm{~min}$. The lungs were then lavaged with prewarmed saline $(1 \mathrm{ml} / 30 \mathrm{~g} \mathrm{BW})$ for 10 times to deplete lung surfactant and ventilated for additional 3.5 hours. Anesthesia and muscle relaxation were maintained by intraperitoneal administration of ketamine/xylazine, and pancuronium bromide, respectively, at a half of the initial dose every $45 \mathrm{~min}$. At the end of ventilation, the rats were sacrificed by severing the descending aorta. The controls were non-lavaged and non-ventilated rats, which were maintained at room air. To fix the lung, three $\mathrm{ml}$ of paraformaldehyde was gently instilled into the left lungs. The instillate sufficiently inflated the lungs. The left bronchus was tied immediately and the left lung en bloc was immersed in the fixative for at least $24 \mathrm{hrs}$. The procedure resulted in uniform fixation without any artifacts. The right lung was removed for RNA analysis.

\section{Histopathology}

Paraffin-embedded left lung specimens were sectioned, placed on glass slides and stained with hematoxylin and eosin for examination by light microscopy. The histopathological lesions were scored by a board-certified veterinary pathologist in a blinded fashion. The lungs were evaluated for the characteristic histopathological changes of ARDS [25]. In each specimen, alveolar septal necrosis, hyaline membrane formation, intravascular (margination) and intraalveolar (infiltration) accumulation of neutrophils and interstitial (perivascular) and intraalveolar edema were graded according to the distribution and severity of each of the changes. The grades were assigned as follows: $0=$ normal; $1=$ occasional fields with minimal changes; $2=$ occasional fields with changes (mild); $3=$ many but not all fields with changes (moderate); $4=$ changes in all fields (severe).

\section{RNA isolation}

Small RNAs were isolated from 4 controls and 4 ARDS rat lungs $(200 \mathrm{mg})$ using the mirVana ${ }^{\mathrm{TM}}$ microRNA isolation kit (Ambion, Austin, TX) exactly as per the instructions of the manufacturer. Total RNAs were isolated from $200 \mathrm{mg}$ of the same lungs used for small RNA isolation by RNA isolation Kit (Ambion, Austin, TX) exactly as per the instructions of the manufacturer. RNA quality and quantity were assessed with agarose gel electrophoresis, A260/A280 ratio and A260/A230 ratio with spectrophotometer (NanoDrop Technologies, Inc, Rockland, DE). The A260/A280 ratios and A260/A230 ratios for all RNA preparations were greater than 1.9 and 2.0, respectively. 
Table 9 Signaling pathways predicted to be regulated by altered miRNAs in ARDS

\begin{tabular}{|c|c|c|}
\hline Pathway & $\begin{array}{c}\text { Target } \\
\text { number }\end{array}$ & Score \\
\hline Axon guidance & 57 & 31.92 \\
\hline ErbB signaling pathway & 37 & 19.04 \\
\hline MAPK signaling pathway & 80 & 17.12 \\
\hline Focal adhesion & 64 & 16.73 \\
\hline Regulation of actin cytoskeleton & 67 & 15.37 \\
\hline Colorectal cancer & 34 & 14.74 \\
\hline Chronic myeloid leukemia & 31 & 14.18 \\
\hline Wnt signaling pathway & 48 & 12.55 \\
\hline Glycan structures - biosynthesis 1 & 40 & 12.39 \\
\hline Glioma & 26 & 12.37 \\
\hline Pancreatic cancer & 28 & 11.05 \\
\hline Renal cell carcinoma & 26 & 9.49 \\
\hline TGF-beta signaling pathway & 31 & 9.33 \\
\hline Small cell lung cancer & 30 & 8.79 \\
\hline Long-term potentiation & 24 & 8.68 \\
\hline Oxidative phosphorylation & 6 & 8.34 \\
\hline Prostate cancer & 30 & 8.22 \\
\hline Circadian rhythm & 8 & 8.17 \\
\hline Arachidonic acid metabolism & 1 & 7.92 \\
\hline mTOR signaling pathway & 20 & 7.78 \\
\hline Antigen processing and presentation & 3 & 7.3 \\
\hline Adherens junction & 25 & 7.01 \\
\hline Acute myeloid leukemia & 21 & 6.96 \\
\hline T cell receptor signaling pathway & 29 & 6.00 \\
\hline Melanoma & 23 & 5.72 \\
\hline Tryptophan metabolism & 1 & 5.68 \\
\hline Endometrial cancer & 18 & 5.31 \\
\hline $\begin{array}{l}\text { Glycosphingolipid biosynthesis - neo- } \\
\text { lactoseries }\end{array}$ & 8 & 5.01 \\
\hline Type II diabetes mellitus & 16 & 4.82 \\
\hline Complement and coagulation cascades & 4 & 4.78 \\
\hline GnRH signaling pathway & 28 & 4.76 \\
\hline Insulin signaling pathway & 37 & 4.44 \\
\hline Melanogenesis & 28 & 4.40 \\
\hline Non-small cell lung cancer & 17 & 4.25 \\
\hline
\end{tabular}

Mapping all the changed miRNAs in ARDS to signaling pathways was performed by DIANA-mirPath software (http://diana.cslab.ece.ntua.gr/pathways). $p<0.01$ was the statistical cutoff for DIANA-miRpath analysis. Target number: The number of miRNA target genes in a given pathway. Score: Enrichment statistical score, the negative natural logarithm of the P-value (-In P).

\section{miRNA microarray}

miRNA microarray analyses were performed on an inhouse platform developed in our laboratory as previously described [60]. The labeling and hybridization of miRNA were performed with the 3 DNA array 900 miRNA direct kit (Genisphere, Hatfield, PA) according to the manufacturer's protocol. Poly (A) tails were added to the enriched miRNA (150 ng) by poly (A) polymerase. The Fluor 3 or Fluor 5 capture sequences were then ligated to the poly (A)-tailed miRNA. Tagged miRNAs were purified with the MinElute PCR Purification Kit (Qiagen, Valencia, CA). Small RNA samples from control and ARDS lungs were separately tagged with Fluor 3 or Fluor 5 capture sequence. After purification, equal amounts of small RNA from all the samples tagged with the same capture sequence were pooled together as a common reference. To eliminate dye bias, dye-swap was performed. The tagged miRNAs were hybridized to a miRNA microarray slide at $52^{\circ} \mathrm{C}$ overnight. The array was washed in pre-warmed $\left(52^{\circ} \mathrm{C}\right) 2 \times \mathrm{SSC}, 0.2 \% \mathrm{SDS}$ for $15 \mathrm{~min}, 2 \times \mathrm{SSC}$ for $12 \mathrm{~min}$, and $0.2 \times$ SSC for $12 \mathrm{~min}$ at room temperature. After washing, the Alexa Fluor 3 or 5 capture reagents were hybridized to the tagged miRNAs at $62^{\circ} \mathrm{C}$ for $4 \mathrm{~h}$. The slides were then washed and dried. The hybridized slide was scanned with ScanArray Express (PerkinElmer Life and Analytical Sciences, Boston, MA), and the images were analyzed with GenePix 5.0 pro (Axon Instruments, Inc. Union City, CA). The signal from each spot was normalized to the average signal of the whole block. The highest and lowest signals from the 6 identical probes in the same block were excluded from the data analysis. The geometric average of the remaining 4 signals was considered to be the signal of that particular miRNA. The ratio of sample signal to reference signal was $\log 2$ transformed. A quality test was performed with Realspot software developed in our laboratory [61]. The miRNAs with an average quality index of $<1$ were filtered. The miRNAs that passed the quality test were analyzed with SAM (Significant Analysis of Microarray) to identify miRNAs that were significantly changed in ARDS $(\mathrm{q}<0.05)$ [62]. A fold change of 1.5 rather than 2 was used as a cut-off value in order to identify more miRNAs.

\section{mRNA microarray}

To identify the altered mRNAs in ARDS, we performed mRNA profiling using an in-house printed DNA microarray including 10,000 rat genes [63]. We designed and printed three blocks in each slide so that we can analyze three biological replicates in the same microarray slide. The two-step microarray hybridization was carried out with the 3DNA 50 Expression kit (Genisphere Inc., Hatfield, PA). The hybridized slides were scanned with ScanArray Express. Raw data were extracted from the DNA microarray hybridization images with GenePix Pro 5. Spot image visualization, spot quality evaluation, data normalization, and SAM test for the identification of the differentially expressed genes were performed as previously described using the RealSpot software [61]. The differentially expressed genes between control and ARDS samples were 


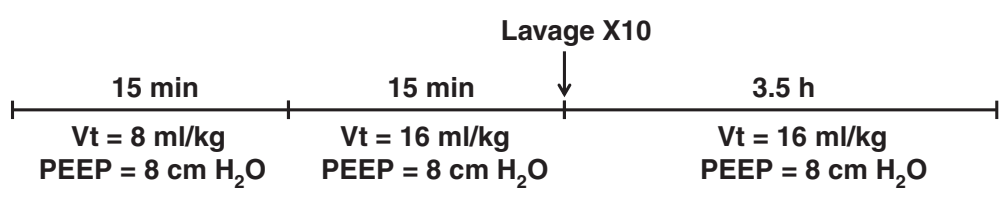

Figure 7 Experimental procedures for a rat model of ARDS.

identified based on both fluorescence intensities and normalized $\log 2$ ratios. Low quality spots with a mean quality index of less than 1.0 were filtered. The genes that passed the quality test were statistically analyzed by SAM test. The genes with a $q$ value of $<0.05$ and a fold change of $\geq 2$ were considered to be the differentially expressed genes.

\section{miRNA quantitative real-time PCR}

Quantitative real-time PCR (qRT-PCR) was used to verify the expression changes of miRNA in ARDS using SYBR Green I [64]. The primers were listed in Table 10. Total RNAs were treated with DNase and purified by Phenol/chloroform extraction and ethanol precipitation. The treated RNAs $(2 \mu \mathrm{g})$ were poly A-tailed and purified by Phenol/chloroform extraction and ethanol precipitation. Poly A-tailed RNAs were reverse-transcribed into cDNA with polyT adapter as the primer. The thermal conditions for real-time PCR were $95^{\circ} \mathrm{C}$ for $10 \mathrm{~min}$, followed by 40 cycles of $95^{\circ} \mathrm{C}$ for $15 \mathrm{sec}, 60^{\circ} \mathrm{C}$ for $30 \mathrm{sec}$, and $65^{\circ} \mathrm{C}$ for $30 \mathrm{sec}$. Data were analyzed using relative quantification based on the comparative $C_{\mathrm{T}}$ method. U6 RNA was used as the endogenous reference.

\section{mRNA quantitative real-time PCR}

qRT-PCR was used to verify the expression change of mRNAs in ARDS. The primers are listed in Table 11. Total RNA $(1 \mu \mathrm{g})$ was reverse-transcribed into cDNA with dT17, random hexamer primer, and MMLV reverse transcriptase. Real-time PCR was run in duplicate at $95^{\circ} \mathrm{C}$ for $10 \mathrm{~min}$, followed by 40 cycles of $95^{\circ} \mathrm{C}$ for $15 \mathrm{sec}, 60^{\circ} \mathrm{C}$ for $30 \mathrm{sec}$, and $65^{\circ} \mathrm{C}$ for $30 \mathrm{sec}$. The relative expression of

Table 10 The primers used for miRNA qPCR

\begin{tabular}{ll}
\hline mo-miR-30b-FW & TGTAAACATCCTACACTCAGCTA \\
rno-miR-99a-FW & AACCCGTAGATCCGATCTTGTG \\
rno-miR-126-FW & TCGTACCGTGAGTAATAATGCGA \\
rno-miR-26a-FW & TTCAAGTAATCCAGGATAGGCTA \\
U6 RNA-FW & GCAAGGATGACACGCAAATTC \\
General-RE & GCGAGCACAGAATTAATACGAC \\
PolyT adapter & GCGAGCACAGAATTAATACGACTCACTATAGGTITITाT \\
& TTTVN \\
\hline
\end{tabular}

genes was determined using the comparative $C_{T}$ method and 18S RNA as a reference.

\section{Bioinformatics analysis}

Functional annotation of mRNA expression profile was conducted by DAVID (The Database for Annotation, Visualization and Integrated Discovery) (http://david.abcc. ncifcrf.gov). DAVID provides a tool for annotating biological meaning for input genes. KEGG pathway enrichment in the altered mRNAs was performed by STIRNG analysis (http://string-db.org/). The interactions of the proteins encoded by altered mRNAs were also determined by STRING. STRING is a web-based tool to investigate protein-protein interactions, KEGG pathway, and GO annotation. Targetscan (http://www.targetscan.org) and miRanda (http://www.microrna.org) were used to predict the mRNAs targeted by the altered miRNAs in ARDS. TargetScan predicts mRNA targets of miRNAs based on conserved and unconserved 8 mer and 7 mer sites in the seed region of 3'-UTR of mRNA. miRanda predicts the miRNA binding sites on mRNAs based on a regression model which uses sequence and contextual features of the predicted miRNA-mRNA pair. All the changed miRNAs were mapped to signaling pathways by DIANA-mirPath software (http://diana.cslab.ece.ntua.gr/pathways). DIANAmirPath utilizes miRNA targets that are predicted with

Table 11 The primers used for mRNA qPCR

\begin{tabular}{ll}
\hline rTIMP1-up & CAGCAAAAGGCCTTCGTAAAGA \\
rTIMP1-down & GATCTGATCTGTCCACAAGCAATG \\
rSOD2-up & GCCTGCACTGAAGTTCAATGG \\
rSOD2-down & CCCAAAGTCACGCTTGATAGC \\
rTSPAN8-down & GCAGTTGGGCCATCATCATG \\
rTSPAN8-up & GGCTACTTGCAGAAGCAGAATCA \\
rACAA2-down & ACGTGAGTGGAGGTGCCATAG \\
rACAA2-up & AAGCTGATCCCACTGCGTATT \\
rMDH1-down & CTACTGAAAGCCAACGTGAAGATC \\
rMDH1-up & AGGCCGTCAGGCAGTTTGTAT \\
rRAMP2-down & TCATCCTACTGAGGACAGCCTTCT \\
rRAMP2-up & CAGTTGCACCAGTCCTTGACA \\
\hline
\end{tabular}


high accuracy and/or experimentally verified targets from TarBase, and perform hierarchical clustering of miRNAs and pathways based on their interaction levels.

\section{Additional file}

\section{Additional file 1: Terms for up regulated gene.}

\section{Competing interests}

The authors declare that they have no competing interests.

\section{Authors' contributions}

$\mathrm{CH}, \mathrm{XX}$ and $\mathrm{NRC}$ carried out experiments. $\mathrm{CH}, \mathrm{XX}, \mathrm{NRC}, \mathrm{MB}$ and $\mathrm{YW}$ analyzed data. $\mathrm{CH}$ and NRC drafted the manuscript. LL conceived of the study, participated in its design and coordination and helped to draft the manuscript. All authors read and approved the final manuscript.

\section{Acknowledgements}

Research reported in this publication was supported by the National Heart, Lung, and Blood Institute of the National Institutes of Health under Award Numbers, R01HL116876, R21 HL087884 and the National Institute of General Medical Sciences under Award number P20GM103648 (Core facilities). The content is solely the responsibility of the authors and does not necessarily represent the official views of the National Institutes of Health.

\section{Author details}

'Department of Physiological Sciences, Lundberg-Kienlen Lung Biology and Toxicology Laboratory, Stillwater, OK, USA. ²Department of Pathobiology, Oklahoma State University, Stillwater, OK, USA. ${ }^{3}$ Oklahoma Center for Respiratory and Infectious Diseases, Oklahoma State University, Stillwater, OK, USA. ${ }^{4}$ Department of Physiological Sciences, Oklahoma State University, 264 McElroy Hall, Stillwater, OK 74078, USA.

Received: 7 October 2013 Accepted: 16 July 2014

Published: 28 July 2014

\section{References}

1. Malhotra A: Low-tidal-volume ventilation in the acute respiratory distress syndrome. N Engl J Med 2007, 357(11):1113-1120.

2. Mikkelsen ME, Shah CV, Meyer NJ, Gaieski DF, Lyon S, Miltiades AN, Goyal M, Fuchs BD, Bellamy SL, Christie JD: The epidemiology of acute respiratory distress syndrome in patients presenting to the emergency department with severe sepsis. Shock 2013, 40(5):375-381.

3. Holland MC, Mackersie RC, Morabito D, Campbell AR, Kivett VA, Patel R, Erickson VR, Pittet JF: The development of acute lung injury is associated with worse neurologic outcome in patients with severe traumatic brain injury. J Trauma 2003, 55(1):106-111.

4. Ferring M, Vincent JL: Is outcome from ARDS related to the severity of respiratory failure? Eur Respir J 1997, 10(6):1297-1300.

5. Rubenfeld GD, Caldwell E, Peabody E, Weaver J, Martin DP, Neff M, Stern EJ, Hudson LD: Incidence and outcomes of acute lung injury. N Engl J Med 2005, 353(16):1685-1693.

6. Grommes J, Soehnlein O: Contribution of neutrophils to acute lung injury. Mol Med 2011, 17(3-4):293-307.

7. Matthay MA, Zemans RL: The acute respiratory distress syndrome: pathogenesis and treatment. Annu Rev Pathol 2011, 6:147-163.

8. Lowe K, Alvarez D, King J, Stevens T: Phenotypic heterogeneity in lung capillary and extra-alveolar endothelial cells. Increased extra-alveolar endothelial permeability is sufficient to decrease compliance. J Surg Res 2007, 143(1):70-77.

9. Wang Y, Brahmakshatriya V, Zhu H, Lupiani B, Reddy SM, Yoon BJ, Gunaratne PH, Kim JH, Chen R, Wang J, Zhou H: Identification of differentially expressed miRNAs in chicken lung and trachea with avian influenza virus infection by a deep sequencing approach. BMC Genomics 2009, 10:512.

10. Lu Y, Okubo T, Rawlins E, Hogan BL: Epithelial progenitor cells of the embryonic lung and the role of microRNAs in their proliferation. Proc Am Thorac Soc 2008, 5(3):300-304.
11. Carraro G, El-Hashash A, Guidolin D, Tiozzo C, Turcatel G, Young BM, De Langhe SP, Bellusci S, Shi W, Parnigotto PP, Warburton D: miR-17 family of microRNAs controls FGF10-mediated embryonic lung epithelial branching morphogenesis through MAPK14 and STAT3 regulation of E-Cadherin distribution. Dev Biol 2009, 333(2):238-250.

12. Bhaskaran M, Wang Y, Zhang H, Weng T, Baviskar P, Guo Y, Gou D, Liu L: MicroRNA-127 modulates fetal lung development. Physiol Genomics 2009, 37(3):268-278.

13. Fish JE, Santoro MM, Morton SU, Yu S, Yeh RF, Wythe JD, Ivey KN, Bruneau $B G$, Stainier DY, Srivastava D: miR-126 regulates angiogenic signaling and vascular integrity. Dev Cell 2008, 15(2):272-284.

14. Wang S, Aurora AB, Johnson BA, Qi X, McAnally J, Hill JA, Richardson JA, Bassel-Duby R, Olson EN: The endothelial-specific microRNA miR-126 governs vascular integrity and angiogenesis. Dev Cell 2008, 15(2):261-271.

15. Vaporidi K, Vergadi E, Kaniaris E, Hatziapostolou M, Lagoudaki E, Georgopoulos D, Zapol WM, Bloch KD, Iliopoulos D: Pulmonary microRNA profiling in a mouse model of ventilator-induced lung injury. Am J Physiol Lung Cell Mol Physiol 2012, 303(3):L199-L207.

16. Zhang X, Peng W, Zhang S, Wang C, He X, Zhang Z, Zhu L, Wang Y, Feng Z: MicroRNA expression profile in hyperoxia-exposed newborn mice during the development of bronchopulmonary dysplasia. Respir Care 2011, 56(7):1009-1015.

17. Bhaskaran M, Xi D, Wang Y, Huang C, Narasaraju T, Shu W, Zhao C, Xiao X, More S, Breshears M, Liu L: Identification of microRNAs changed in the neonatal lungs in response to hyperoxia exposure. Physiol Genomics 2012, 44(20):970-980.

18. Ezzie ME, Crawford M, Cho JH, Orellana R, Zhang S, Gelinas R, Batte K, Yu L, Nuovo G, Galas D, Diaz P, Wang K, Nana-Sinkam SP: Gene expression networks in COPD: microRNA and mRNA regulation. Thorax 2012, 67(2):122-131.

19. Pottelberge GR, Mestdagh P, Bracke KR, Thas O, Durme YM, Joos GF, Vandesompele J, Brusselle GG: MicroRNA expression in induced sputum of smokers and patients with chronic obstructive pulmonary disease. Am J Respir Crit Care Med 2011, 183(7):898-906.

20. Pandit KV, Corcoran D, Yousef H, Yarlagadda M, Tzouvelekis A, Gibson KF, Konishi K, Yousem SA, Singh M, Handley D, Richards T, Selman M, Watkins SC, Pardo A, Ben-Yehudah A, Bouros D, Eickelberg O, Ray P, Benos PV, Kaminski N: Inhibition and role of let-7d in idiopathic pulmonary fibrosis. Am J Respir Crit Care Med 2010, 182(2):220-229.

21. Liu G, Friggeri A, Yang Y, Milosevic J, Ding Q, Thannickal VJ, Kaminski N, Abraham E: miR-21 mediates fibrogenic activation of pulmonary fibroblasts and lung fibrosis. J Exp Med 2010, 207(8):1589-1597.

22. Ware LB, Matthay MA: The acute respiratory distress syndrome. N Engl J Med 2000, 342(18):1334-1349.

23. Meyer NJ, Garcia JG: Wading into the genomic pool to unravel acute lung injury genetics. Proc Am Thorac Soc 2007, 4(1):69-76.

24. Zhou T, Garcia JG, Zhang W: Integrating microRNAs into a system biology approach to acute lung injury. Transl Res 2011, 157(4):180-190.

25. Germann PG, Hafner D: A rat model of acute respiratory distress syndrome (ARDS): Part 1. Time dependency of histological and pathological changes. J Pharmacol Toxicol Methods 1998, 40(2):101-107.

26. Yen CC, Lai YW, Chen HL, Lai CW, Lin CY, Chen W, Kuan YP, Hsu WH, Chen CM: Aerosolized human extracellular superoxide dismutase prevents hyperoxia-induced lung injury. PLoS One 2011, 6(10):e26870.

27. Kim KH, Burkhart K, Chen P, Frevert CW, Randolph-Habecker J, Hackman RC, Soloway PD, Madtes DK: Tissue inhibitor of metalloproteinase-1 deficiency amplifies acute lung injury in bleomycin-exposed mice. Am J Respir Cell Mol Biol 2005, 33(3):271-279.

28. Yue W, Dacic S, Sun Q, Landreneau R, Guo M, Zhou W, Siegfried JM, Yu J, Zhang L: Frequent inactivation of RAMP2, EFEMP1 and Dutt1 in lung cancer by promoter hypermethylation. Clin Cancer Res 2007, 13(15 Pt 1):4336-4344.

29. Nazarenko I, Rana S, Baumann A, McAlear J, Hellwig A, Trendelenburg M, Lochnit G, Preissner KT, Zoller M: Cell surface tetraspanin Tspan8 contributes to molecular pathways of exosome-induced endothelial cell activation. Cancer Res 2010, 70(4):1668-1678.

30. da Huang W, Sherman BT, Lempicki RA: Systematic and integrative analysis of large gene lists using DAVID bioinformatics resources. Nat Protoc 2009, 4(1):44-57.

31. da Huang W, Sherman BT, Tan Q, Kir J, Liu D, Bryant D, Guo Y, Stephens R, Baseler MW, Lane HC, Lempicki RA: DAVID Bioinformatics Resources: 
expanded annotation database and novel algorithms to better extract biology from large gene lists. Nucleic Acids Res 2007, 35:W169-W175.

32. Papadopoulos GL, Alexiou P, Maragkakis M, Reczko M, Hatzigeorgiou AG: DIANA-mirPath: Integrating human and mouse microRNAs in pathways. Bioinformatics 2009, 25(15):1991-1993.

33. Downey GP, Dong Q, Kruger J, Dedhar S, Cherapanov V: Regulation of neutrophil activation in acute lung injury. Chest 1999, 116(1 Suppl):46S-54S

34. Martin TR: Cytokines and the acute respiratory distress syndrome (ARDS): a question of balance. Nat Med 1997, 3(3):272-273.

35. Wada T, Jesmin S, Gando S, Yanagida Y, Mizugaki A, Sultana SN, Zaedi S, Yokota $\mathrm{H}$ : The role of angiogenic factors and their soluble receptors in acute lung injury (ALI)/acute respiratory distress syndrome (ARDS) associated with critical illness. J Inflamm (Lond) 2013, 10(1):6.

36. Medford AR, Godinho SI, Keen LJ, Bidwell JL, Millar AB: Relationship between vascular endothelial growth factor + 936 genotype and plasma/ epithelial lining fluid vascular endothelial growth factor protein levels in patients with and at risk for ARDS. Chest 2009, 136(2):457-464

37. Laurent T, Markert M, Feihl F, Schaller MD, Perret C: Oxidant-antioxidant balance in granulocytes during ARDS. Effect of N-acetylcysteine. Chest 1996, 109(1):163-166

38. Suarez $Y$, Sessa WC: MicroRNAs as novel regulators of angiogenesis. Circ Res 2009, 104(4):442-454.

39. Chi SW, Zang JB, Mele A, Darnell RB: Argonaute HITS-CLIP decodes microRNA-mRNA interaction maps. Nature 2009, 460(7254):479-486.

40. Bardales RH, Xie SS, Schaefer RF, Hsu SM: Apoptosis is a major pathway responsible for the resolution of type II pneumocytes in acute lung injury. Am J Pathol 1996, 149(3):845-852.

41. Lee KS, Choi YH, Kim YS, Baik SH, Oh YJ, Sheen SS, Park JH, Hwang SC, Park KJ: Evaluation of bronchoalveolar lavage fluid from ARDS patients with regard to apoptosis. Respir Med 2008, 102(3):464-469.

42. Suh JH, Choi E, Cha MJ, Song BW, Ham O, Lee SY, Yoon C, Lee CY, Park JH, Lee $\mathrm{SH}$, Hwang KC: Up-regulation of miR-26a promotes apoptosis of hypoxic rat neonatal cardiomyocytes by repressing GSK-3beta protein expression. Biochem Biophys Res Commun 2012, 423(2):404-410.

43. Zhang B, Liu XX, He JR, Zhou CX, Guo M, He M, Li MF, Chen GQ, Zhao Q: Pathologically decreased miR-26a antagonizes apoptosis and facilitates carcinogenesis by targeting $\mathrm{MTDH}$ and $\mathrm{EZH} 2$ in breast cancer. Carcinogenesis 2011, 32(1):2-9.

44. Barh D, Malhotra R, Ravi B, Sindhurani P: MicroRNA let-7: an emerging next-generation cancer therapeutic. Curr Oncol 2010, 17(1):70-80.

45. Oglesby IK, Bray IM, Chotirmall SH, Stallings RL, O'Neill SJ, McElvaney NG, Greene CM: miR-126 is downregulated in cystic fibrosis airway epithelial cells and regulates TOM1 expression. J Immunol 2010, 184(4):1702-1709.

46. Franchina T, Amodeo V, Bronte G, Savio G, Ricciardi GR, Picciotto M, Russo A, Giordano A, Adamo V: Circulating miR-22, miR-24 and miR-34a as novel predictive biomarkers to pemetrexed-based chemotherapy in advanced non small cell lung cancer. J Cell Physio/ 2013, 229(1):97-99.

47. Oneyama C, Ikeda J, Okuzaki D, Suzuki K, Kanou T, Shintani Y, Morii E, Okumura M, Aozasa K, Okada M: MicroRNA-mediated downregulation of mTOR/FGFR3 controls tumor growth induced by Src-related oncogenic pathways. Oncogene 2011, 30(32):3489-3501.

48. Hayes DN, McLeod HL: EGFR regulation by microRNA in lung cancer: a rose by any other name ... is an increasingly complicated rose. Ann Oncol 2008, 19(6):1036-1037.

49. Lin CW, Chang YL, Chang YC, Lin JC, Chen CC, Pan SH, Wu CT, Chen HY, Yang SC, Hong TM, Yang PC: MicroRNA-135b promotes lung cancer metastasis by regulating multiple targets in the Hippo pathway and LZTS1. Nat Comm 2013, 4:1877.

50. Kumarswamy R, Mudduluru G, Ceppi P, Muppala S, Kozlowski M, Niklinski J, Papotti M, Allgayer H: MicroRNA-30a inhibits epithelial-to-mesenchymal transition by targeting Snai1 and is downregulated in non-small cell lung cancer. Int J Cancer 2012, 130(9):2044-2053.

51. Kumar M, Ahmad T, Sharma A, Mabalirajan U, Kulshreshtha A, Agrawal A, Ghosh B: Let-7 microRNA-mediated regulation of IL-13 and allergic airway inflammation. J Allergy Clin Immunol 2011, 128(5):1077-1085. e1071-1010.

52. Poissonnier $L$, Villain $G$, Soncin F, Mattot V: miR126-5p repression of ALCAM and SetD5 in endothelial cells regulates leucocyte adhesion and transmigration. Cardiovasc Res 2014, 102(3):436-447.

53. Lang JD, McArdle PJ, O'Reilly PJ, Matalon S: Oxidant-antioxidant balance in acute lung injury. Chest 2002, 122(6 Suppl):314S-320S.
54. Trujillo G, Zhang J, Habiel DM, Ge L, Ramadass M, Ghebrehiwet B, Kew RR: Cofactor regulation of $\mathrm{C} 5$ a chemotactic activity in physiological fluids. Requirement for the vitamin D binding protein, thrombospondin-1 and its receptors. Mol Immunol 2011, 49(3):495-503.

55. Sabharwal AK, Bajaj SP, Ameri A, Tricomi SM, Hyers TM, Dahms TE, Taylor FB Jr, Bajaj MS: Tissue factor pathway inhibitor and von Willebrand factor antigen levels in adult respiratory distress syndrome and in a primate model of sepsis. Am J Respir Crit Care Med 1995, 151(3 Pt 1):758-767.

56. Moss M, Ackerson L, Gillespie MK, Moore FA, Moore EE, Parsons PE: von Willebrand factor antigen levels are not predictive for the adult respiratory distress syndrome. Am J Respir Crit Care Med 1995, 151(1):15-20.

57. Moss M, Standiford TJ: Leptin in fibroproliferative acute respiratory distress syndrome: not just a satiety factor. Am J Respir Crit Care Med 2011, 183(11):1443-1444

58. Villar J, Cabrera NE, Casula M, Valladares F, Flores C, Lopez-Aguilar J, Blanch L, Zhang $\mathrm{H}$, Kacmarek RM, Slutsky AS: WNT/beta-catenin signaling is modulated by mechanical ventilation in an experimental model of acute lung injury. Intensive Care Med 2011, 37(7):1201-1209.

59. Hafner D, Germann PG: A rat model of acute respiratory distress syndrome (ARDS) Part 2, influence of lavage volume, lavage repetition, and therapeutic treatment with rSP-C surfactant. J Pharmacol Toxicol Methods 1999, 41(2-3):97-106.

60. Wang Y, Weng T, Gou D, Chen Z, Chintagari NR, Liu L: Identification of rat lung-specific microRNAs by micoRNA microarray: valuable discoveries for the facilitation of lung research. BMC Genomics 2007, 8:29

61. Chen Z, Liu L: RealSpot: software validating results from DNA microarray data analysis with spot images. Physiol Genomics 2005, 21(2):284-291.

62. Tusher VG, Tibshirani R, Chu G: Significance analysis of microarrays applied to the ionizing radiation response. Proc Natl Acad Sci U S A 2001, 98(9):5116-5121.

63. Chen Z, Chen J, Weng T, Jin N, Liu L: Identification of rat lung-prominent genes by a parallel DNA microarray hybridization. BMC Genomics 2006, 7:47.

64. Shi $R$, Chiang VL: Facile means for quantifying microRNA expression by real-time PCR. Biotechniques 2005, 39(4):519-525.

doi:10.1186/1755-8794-7-46

Cite this article as: Huang et al:: MicroRNA and mRNA expression profiling in rat acute respiratory distress syndrome. BMC Medical Genomics 2014 7:46.

\section{Submit your next manuscript to BioMed Central and take full advantage of:}

- Convenient online submission

- Thorough peer review

- No space constraints or color figure charges

- Immediate publication on acceptance

- Inclusion in PubMed, CAS, Scopus and Google Scholar

- Research which is freely available for redistribution 